\title{
Biobenefication of Oxide Minerals from Bacillus subtilis Using FTIR and MALDI-TOF Techniques
}

\author{
H. Sarvamangala ${ }^{1}$, Vinay B. Raghavendra ${ }^{2}$, S. T. Girisha ${ }^{1^{*}}$ \\ ${ }^{1}$ Department of Microbiology and Biotechnology, Bangalore University, Bengaluru, India \\ ${ }^{2}$ Teresian Research Center, Siddarthanagar, Mysore, India \\ Email: *stgirisha@gmail.com
}

How to cite this paper: Sarvamangala, H., Raghavendra, V.B. and Girisha, S.T. (2017) Biobenefication of Oxide Minerals from Bacillus subtilis Using FTIR and MALDITOF Techniques. Journal of Environmental Protection, 8, 194-205.

https://doi.org/10.4236/jep.2017.82015

Received: December 15, 2016

Accepted: February 25, 2017

Published: February 28, 2017

Copyright $\odot 2017$ by authors and Scientific Research Publishing Inc. This work is licensed under the Creative Commons Attribution International License (CC BY 4.0).

http://creativecommons.org/licenses/by/4.0/

\begin{abstract}
Biobeneficiation processes involving the separation of valuable minerals from ores and materials using conventional flotation and flocculation methods have been shown to be promising in recent years. There is an enormous potential to utilize microorganisms as flocculating agents, flotation collectors and/or depressants. The study involves Biobeneficiation of oxide minerals using Bacillus subtilis. Characterization of minerals (hematite, corundum, calcite and quartz) was carried out through XRD, EDAX and FTIR techniques. FTIR of minerals before and after interaction with cells, cell free extract and extracellular proteins was carried out and it has been found that there is a shift or change in the peaks of functional groups. In presence of protein adsorption, amide peaks were found and in case of polysaccharide adsorption, carboxyl peaks were found which justify the flotation and flocculation results. MALDITOF was carried out to confirm the molecular weights of the extracted proteins and it was found that molecular weight of proteins on interaction with minerals was higher than that of uninteracted minerals.
\end{abstract}

\section{Keywords}

Biobeneficiation, FTIR, MALDI-TOF, Bacillus subtilis, Oxide Minerals

\section{Introduction}

Ever increasing demand for iron ores has led to exploitation of even lean grade ores and fines. Effective utilization of lean grade ores, iron ore fines and processed wastes brings about efficient beneficiation processes which are environment-friendly, cost-effective and energy-efficient, hence biotechnological processes have been attracting attention in mineral processing industry. Advent of biotechnology in mineral processing has opened up immense possibilities to exploit difficult to treat ores; thus bioprocessing techniques hold promise as po- 
tential substitutes for conventional technologies in vogue [1].

Among oxide minerals hematite is the most abundant and important iron bearing mineral widely used in iron and steel industries, but it is associated with oxide gangue minerals. Iron ore consists of hematite and gangue minerals like corundum, calcite and quartz. Various physico-chemical methods used to separate gangue minerals from hematite are considered to be expensive and are not eco-friendly [2]. It becomes imperative to separate hematite from other gangue minerals; hence the research work was focused on development of biobeneficiation processes for oxide minerals such as hematite, corundum, calcite and quartz with relevance to iron ore.

In the present investigation, $B$. subtilis a gram-positive, neutrophilic, periflagellated heterotroph indigenous bacterium associated with many mineral deposits was used. Extracellular polysaccharides, lipoproteins are the principal components of biomass obtained from B. subtilis [3] [4].

Characterization of minerals was carried out by XRD, EDAX and FTIR. Fourier transform infra red spectroscopy (FTIR) was further used to observe the changes in peaks of the functional groups of minerals before and after interaction with cells, cell free extract and extracellular proteins [5]. Matrix assisted laser desorption ionization-time of flight (MALDI-TOF) was utilized to confirm the molecular weights of extracellular bacterial proteins before and after interaction with minerals. Similar findings have been reported in case of cytosolic proteins of Ferrooxidans [6].

\section{Materials and Methods}

Minerals: Mineral samples of hematite, corundum (alumina), calcite and quartz were obtained from Alminrock, Indscer Fabriks, Bangalore, India. Samples were ground in a porcelain ball mill and sieved to obtain different size factions. The surface area was estimated by Brunauer-Emmett-Teller (BET) nitrogen specific surface area method using Micromeritics Flowsorb II 200 surface area analyser. The SEM micrographs of ground minerals were taken.

Characterization of minerals: Minerals obtained were characterized prior to their use in the experiments in order to ascertain their purity, acquire chemical composition and have prior knowledge of their structural characteristics. Characterization was carried out with different techniques such as chemical analysis, $\mathrm{X}$-ray diffraction photometry and Energy dispersive X-ray dispersion (EDAX) analysis.

1) Chemical analysis: Chemical analysis was carried out using standard wet chemical analytical techniques of acid digestion by Indian Bureau of Mines, Bangalore [7].

2) X-ray diffraction photometry analysis: X-ray diffraction studies were carried out with model JDX-8030, JEOL Limited, Tokyo, Japan [8].

3) Energy dispersive X-ray analysis (EDAX): EDAX studies were carried out using a FEI Sirion, high resolution electron microscope [9].

Bacteria: Strain of B. subtilis (NCIM 2655) used in this study was obtained 
from the National Collection of Industrial Microorganisms, National Chemical Laboratory, Pune, India. It was sub cultured in the laboratory using Luria broth medium (LB) and the growth kinetics were studied. B. subtilis was cultured by inoculating a fully grown culture with $10^{9}$ cells $/ \mathrm{ml}$ of pure strain to Luria broth (LB) medium and incubated at $30^{\circ} \mathrm{C}$ on a Scigenics Orbitek rotary shaker at 200 rpm. Cell concentration was determined with a Petroff-Hausser counting chamber under a Leitz phase contrast microscope (LABORLUX K Wild MPS 12). The $\mathrm{pH}$ of the grown culture medium was 7.7 - 7.8. Cells of B. subtilis were also grown in presence of pyrite and galena in LB medium at $5 \%$ pulp density through serial sub culturing. Adaptation to minerals was considered achieved when the growth rate of adapted strain was identical to that of the control (cells grown in absence of minerals). Fully grown culture of B. subtilis was taken and subjected to centrifugation at $10,000 \times \mathrm{g}$ using a bench top centrifuge (Heraeus Biofuge Stratos) for $10 \mathrm{~min}$ at $4^{\circ} \mathrm{C}$. Cell pellet was suspended in $10^{-3} \mathrm{M} \mathrm{KNO}_{3}$ and placed in refrigerator till further use. The supernatant was collected and filtered through a $0.2 \mu \mathrm{m}$ sterile membrane using Millipore vacuum suction pump to make it cell free [10].

Fourier transform infrared (FTIR) studies: For studying characteristics of surface functional groups of cell, cell free extract and extracellular proteins of interacted minerals and also characterization of secreted biopolymers IR studies were carried using a Perkin Elmer Model FT Spectrum-1000 instrument, operating in the $4000-400 \mathrm{~cm}^{-1}$ range. IR spectrum of minerals after interaction with various bioreagents was taken. FTIR spectrum of extracellular polysaccharides and cell wall polysaccharides were also carried to obtain insight in course of structural characterization of ECP. FTIR spectrums were obtained using $\mathrm{KBr}$ pellet technique. Since $\mathrm{KBr}$ is transparent to InfraRed rays approximately $2 \mathrm{mg}$ of the desired powder was thoroughly mixed with $200 \mathrm{mg}$ of spectrometry grade $\mathrm{KBr}$ and then placed in sample holder by pressing it and making a thin layer for recording as transmission of Infra red through spectrophotometer [11] [12].

Mass spectrometry: Molecular weight of bioreagents was measured with Kompact (SEQ) KRATOS analytical time of flight mass spectrometry and with Matrix Assisted Laser Desorption/Ionisation (MALDI) [13].

\section{Results}

Prior to commencing this research investigation in microbe-mineral interaction, it was an imperative to know the details of minerals. Hence various characterization techniques such as mineralogical analysis, X-ray diffraction studies, energy dispersive X-ray analysis (EDAX), particle size determination, particle surface area analysis, SEM studies etc. The peaks observed assured the purity of individual minerals and the purity were found to be $95 \%, 97 \%$, 99\%, 99\% respectively for hematite, corundum, calcite and quartz.

Surface area of minerals by Brunauer-Emmett-Teller (BET) analyzer was found to be $1.2 \mathrm{~m}^{2} / \mathrm{g}$ for hematite, $1.95 \mathrm{~m}^{2} / \mathrm{g}$ for corundum, $1.653 \mathrm{~m}^{2} / \mathrm{g}$ for calcite and $2.659 \mathrm{~m}^{2} / \mathrm{g}$ for quartz. 
With relevance to iron ore beneficiation, growth kinetics of $B$. subtilis cells exhibited highest affinity towards hematite $\left(10^{9} \mathrm{cells} / \mathrm{g}\right)$, when compared to corundum, calcite and quartz. Bacterial adhesion was observed to be significantly higher on hematite and hematite could be effectively separated from corundum, calcite and quartz through microbially induced selective flocculation and flotation.

Extracellular protein exhibited higher affinity towards quartz compared to calcite and corundum and extracellular protein exhibited lower affinity towards hematite. Mineral induced proteins were expressed when bacterial cells were adapted to quartz, corundum, calcite and hematite. Mineral specific intracellular proteins were expressed when bacterial cells were grown in presence of hematite, corundum, calcite and quartz. B. subtilis grown in presence of quartz secreted specific proteins, such as $19.9,33.5,40.2,60.3 \mathrm{kDa}$ and these proteins were not secreted in control. Protein band of about $22.39 \mathrm{kDa}$ was seen in case of control which was not present in mineral grown strains. In case of intracellular protein of B. subtilis grown in presence of hematite and quartz secreted a conspicuous thick band of proteins of 14 to $25 \mathrm{kDa}$ range which was not expressed in control.

Hydrophobicity of cells grown in absence and presence of minerals was studied and it showed the hydrophobic nature of corundum (90\%), calcite (90\%) and quartz (90\%) interacted bacterial cells and in presence of hematite, cells became more hydrophilic.

Flocculation studies carried out in presence of bacterial cells and cell free extract showed that settling rate of hematite was significantly higher than that of quartz, calcite and corundum. Percent flotation recovery of quartz was $92.3 \% \pm$ $1.0 \%$ on interaction with bacterial cells and with cell free extract the recovery was $90.8 \% \pm 0.8 \%$ and that of corundum and calcite showed a recovery of $71.7 \pm$ 0.8 and $75.2 \% \pm 0.8 \%$ respectively. Hematite flotation was highly impaired ( $4.7 \pm$ 0.6 and $2.4 \% \pm 0.9 \%)$. Similar results were obtained in case of flocculation and flotation studies with the binary mixtures of minerals.

FTIR studies showed significant appearance of new functional groups on interaction of minerals with cells, cell free extract and extracellular proteins. MALDI-TOF results showed the secretion of higher molecular weight of proteins and these results are in accord with those obtained by SDS-PAGE analyses.

FTIR studies: FTIR spectra of hematite shows three IR bands at 528, 490 and $348.32 \mathrm{~cm}^{-1}$ which were attributed to hydroxyl groups. The $950 \mathrm{~cm}^{-1}$ absorption band could be due to hydroxyl groups, being the corresponding deformation modes of the $\mathrm{OH}$ stretching absorption due to surface hydroxyls reported in hematite (Rochester 1979). FTIR spectra of corundum showed band at 3400 $\mathrm{cm}^{-1}$ is assigned to $-\mathrm{OH}$ stretching vibration of hydroxyls, $969 \mathrm{~cm}^{-1}$ are assigned to the bending vibrations of $\mathrm{Al}-\mathrm{OH}$ and the band at $603 \mathrm{~cm}^{-1}$ is assigned to the symmetric stretching mode of Al-O bond. In case of calcite, characteristic peak of the carbonate ion at $1409 \mathrm{~cm}^{-1}$ a sharp absorption band at $874 \mathrm{~cm}^{-1}$ and a broad band around $708 \mathrm{~cm}^{-1}$ and sharp peak at $356 \mathrm{~cm}^{-1}$ were observed. For quartz, the mid infra red spectra range of $400-1200 \mathrm{~cm}^{-1}$ are classified in to four 
characteristic bands around $1078 \mathrm{~cm}^{-1}, 750 \mathrm{~cm}, 1500 \mathrm{~cm}^{-1}$ and $353 \mathrm{~cm}^{-1}$.

FTIR spectrum of control (cells) and interacted minerals are given in (Figure 1(a) and Figure 1(b)). On interaction with control (cells), new functional groups were observed on hematite; $2936 \mathrm{~cm}^{-1}(\mathrm{~m})$ with $\mathrm{C}-\mathrm{H}$ stretch shows the presence of alkanes, $642 \mathrm{~cm}^{-1}(\mathrm{~b}, \mathrm{~s})$ with $-\mathrm{C}=\mathrm{C}-\mathrm{H}$; C-H bend shows the presence of alkynes, and $538 \mathrm{~cm}^{-1}(\mathrm{~m})$ with $\mathrm{C}-\mathrm{Br}$ stretch shows alkyl halides and these peaks are absent in cells and uninteracted minerals. On interaction with corundum shifts in the peaks were observed for $1654 \mathrm{~cm}^{-1}(\mathrm{~m})$ with $\mathrm{N}-\mathrm{H}$ bend shows the presence of $1^{\circ}$ amines and $1078 \mathrm{~cm}^{-1}(\mathrm{~m})$ with C-O stretch shows ethers, 965 $\mathrm{cm}^{-1}$ (s) with $\mathrm{C}-\mathrm{H}$ bend shows the presence of alkenes which were not seen on cells and uninteracted corundum. FTIR studies for control as well as calcite and quartz on interaction with cells were conducted and the spectra are shown in (Figure 2(a) and Figure 2(b)). In case of calcite the peaks are very sharp and

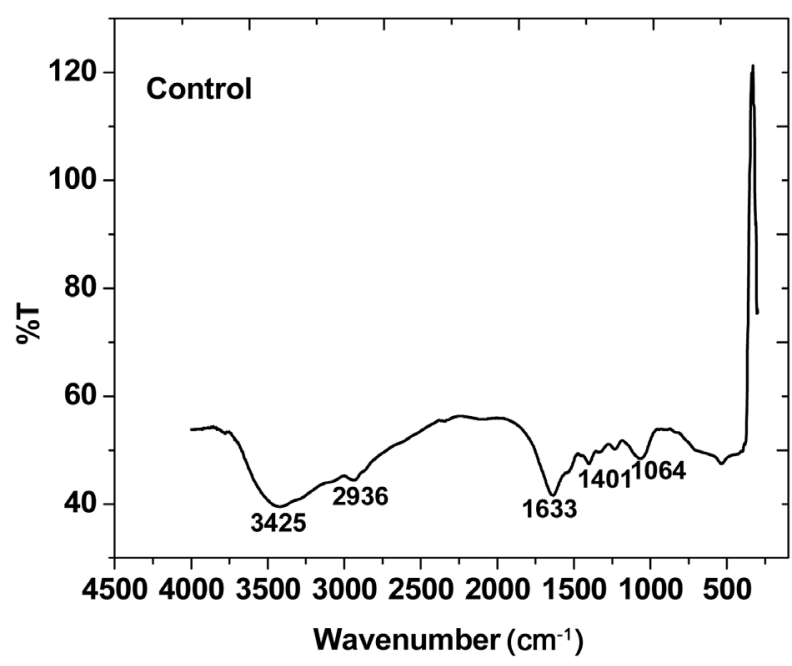

(a)

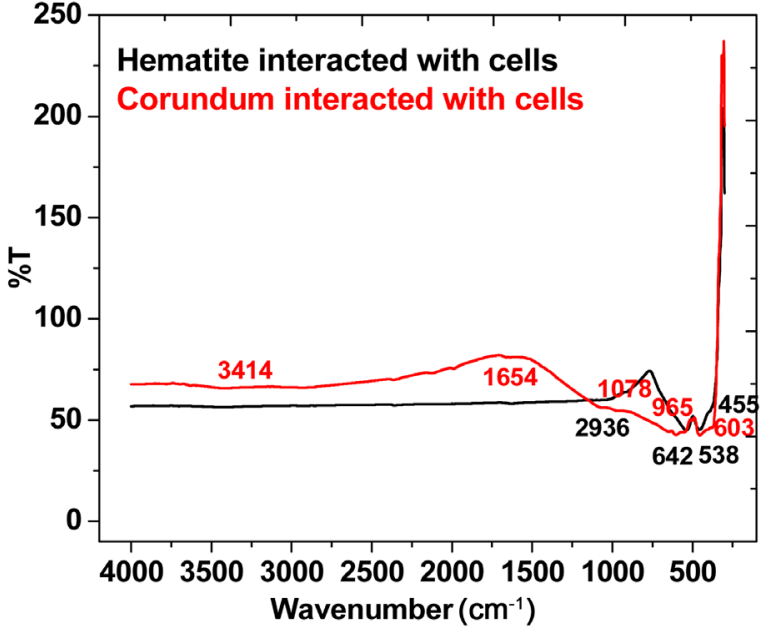

(b)

Figure 1. FTIR spectra of (a) Cell (control) and (b) Interacted hematite and corundum.

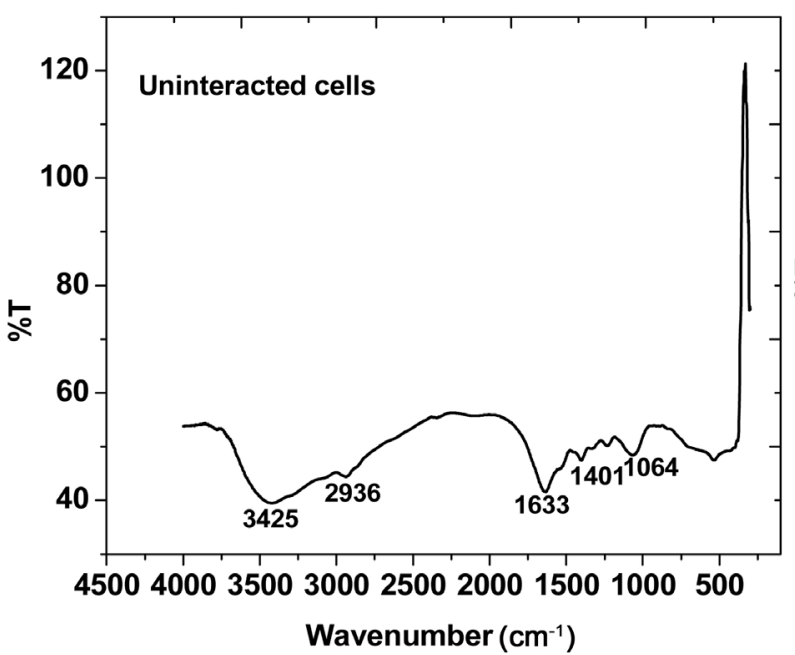

(a)

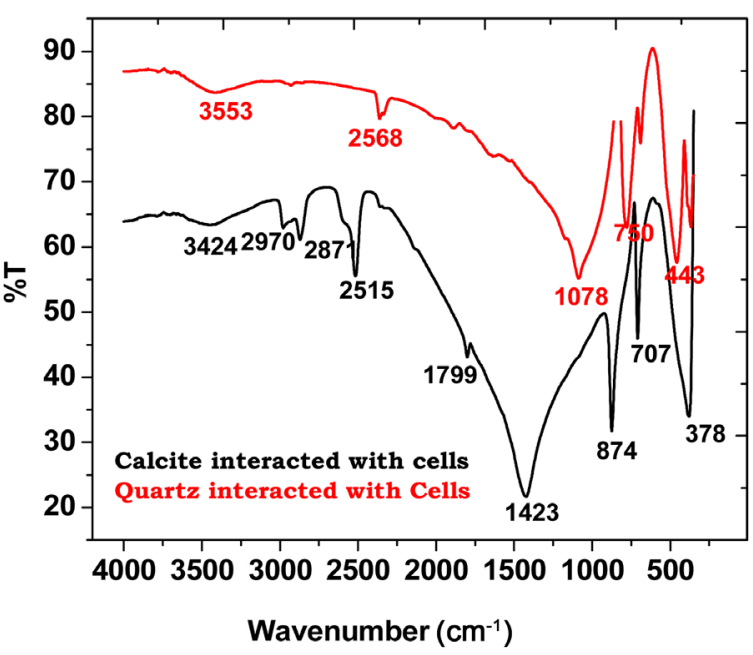

(b)

Figure 2. FTIR spectra of (a) Cell (control) and (b) Interacted calcite and quartz. 
new peaks which were not observed in control and uninteracted calcite were found to be $2515 \mathrm{~cm}^{-1}$ (b) with O-H shows carboxylic acids, $1799 \mathrm{~cm}^{-1}$ (s) with $\mathrm{C}=\mathrm{O}$ shows dominated carbonate peak [14]. As seen in case of quartz, new species of functional groups present were that of $2568 \mathrm{~cm}^{-1}$ (b) with $\mathrm{O}-\mathrm{H}$ shows carboxylic acids, $1078 \mathrm{~cm}^{-1}(\mathrm{~m})$ with $\mathrm{C}-\mathrm{O}$ stretch shows ether groups, and 750 $\mathrm{cm}^{-1}(\mathrm{~s})$ with $=\mathrm{C}-\mathrm{H}$ and $\mathrm{C}=\mathrm{C}$ shows phenyl groups.

The FTIR spectra of cell free extract interacted with minerals is given in (Figure 3(a) and Figure 3(b)). Cell free extract of bacteria is found to show the presence of polysaccharides and proteins and on interaction with minerals, hematite showed the presence of $537 \mathrm{~cm}^{-1}(\mathrm{~m})$ with $\mathrm{C}-\mathrm{Br}$ stretch which is due to the presence of alkyl halides groups and $438 \mathrm{~cm}^{-1}(\mathrm{~m})$ gives the peaks of hematite and there is no peak of cell free extract. On interaction with corundum, it gives the peaks at $960-1067 \mathrm{~cm}^{-1}$ which is assigned to the bending vibrations of $\mathrm{Al}-\mathrm{OH}$ and the peak at $602 \mathrm{~cm}^{-1}$ is a stretch peak of Al-O bond as well as 1067 $\mathrm{cm}^{-1}(\mathrm{~m})$ with C-N stretch shows the presence of aliphatic amine groups.

FTIR spectra of calcite and quartz before and after interaction with cell free extract is shown in (Figure 4(a) and Figure 4(b)). On interaction with cell free extract, new species found on calcite were $2516 \mathrm{~cm}^{-1}$ (b) with $\mathrm{O}-\mathrm{H}$ shows the presence of carboxylic acids, $1800 \mathrm{~cm}^{-1}$ (s) with $\mathrm{C}=\mathrm{O}$ shows amides, ketones, aldehydes, carboxylic acids and esters, $1424 \mathrm{~cm}^{-1}(\mathrm{~m})$ with C-C stretch shows the presence of aromatic groups. $875 \mathrm{~cm}^{-1}(\mathrm{~m})$ with $\mathrm{C}-\mathrm{H}$ "oop" shows aromatics groups $708 \mathrm{~cm}^{-1}$ (b, s) with $-\mathrm{C}=\mathrm{C}-\mathrm{H}$; C-H bend shows the presence of alkynes. As seen in quartz, new groups were $1994 \mathrm{~cm}^{-1}(\mathrm{w})$ with $-\mathrm{C}=\mathrm{C}$ - stretch which show the presence of alkyne groups, $1084 \mathrm{~cm}^{-1}(\mathrm{~m})$ with $\mathrm{C}-\mathrm{N}$ stretch shows aliphatic amine groups and $779 \mathrm{~cm}^{-1}(\mathrm{~m})$ with $\mathrm{C}-\mathrm{H}$ "oop” shows aromatics groups.

Finally FTIR studies were carried out for all the four minerals on interaction with extracellular proteins and are given in (Figure 5(a) and Figure 5(b)). The

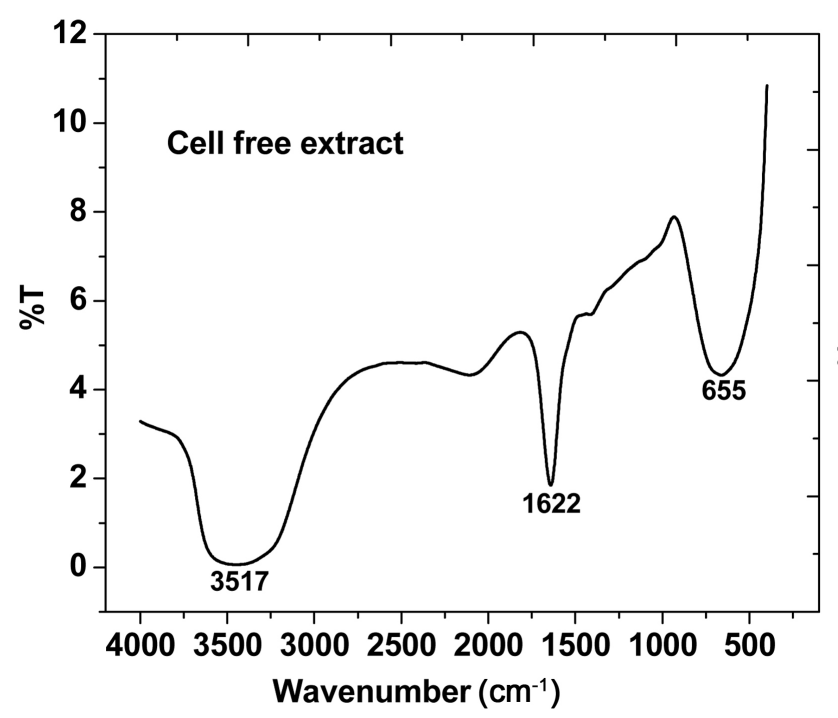

(a)

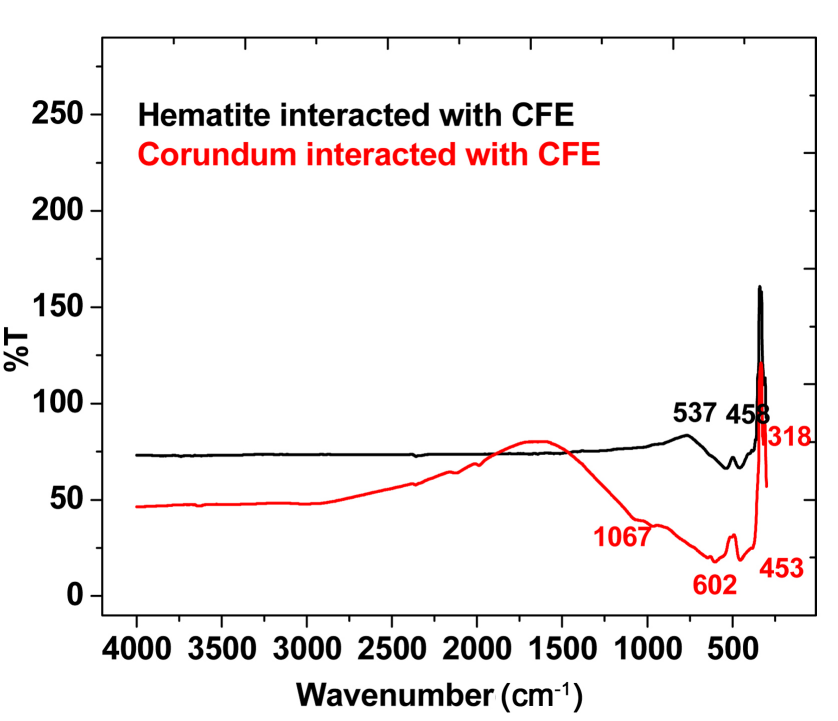

(b)

Figure 3. FTIR spectra of (a) Cell free extract and (b) Interacted hematite and corundum. 


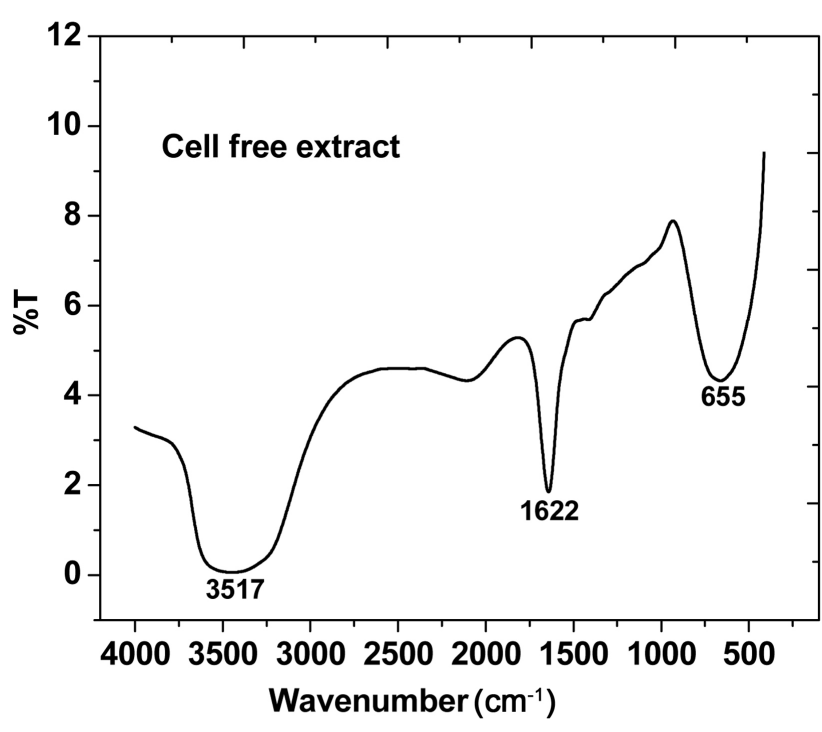

(a)

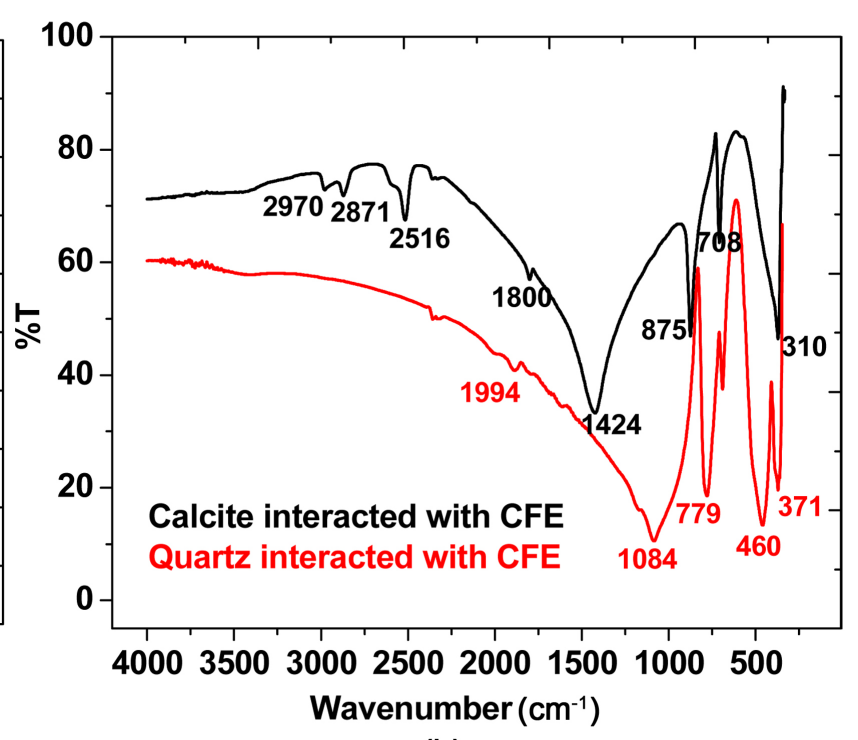

(b)

Figure 4. FTIR spectra of (a) Cell free extract and (b) Interacted calcite and quartz.

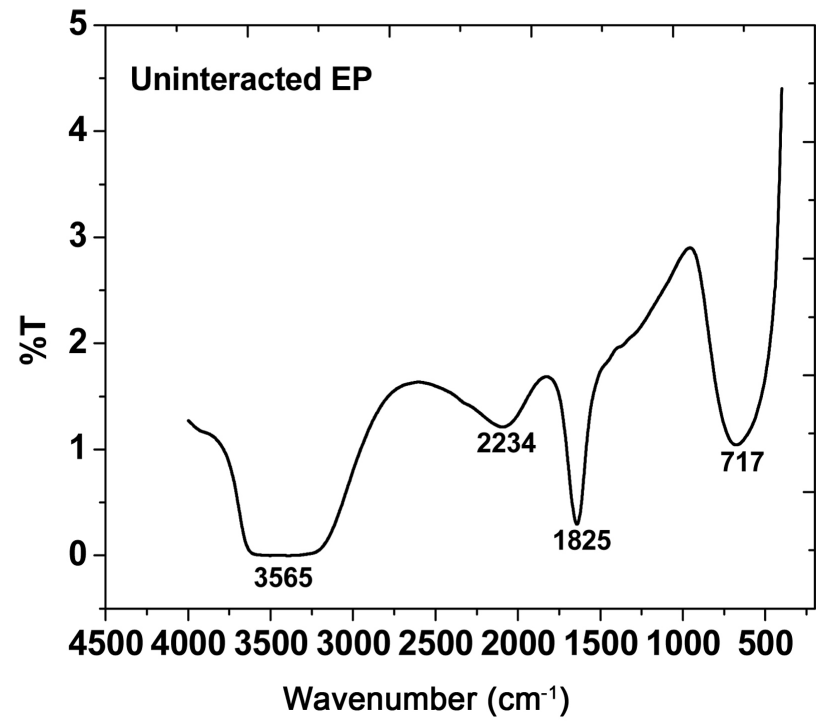

(a)

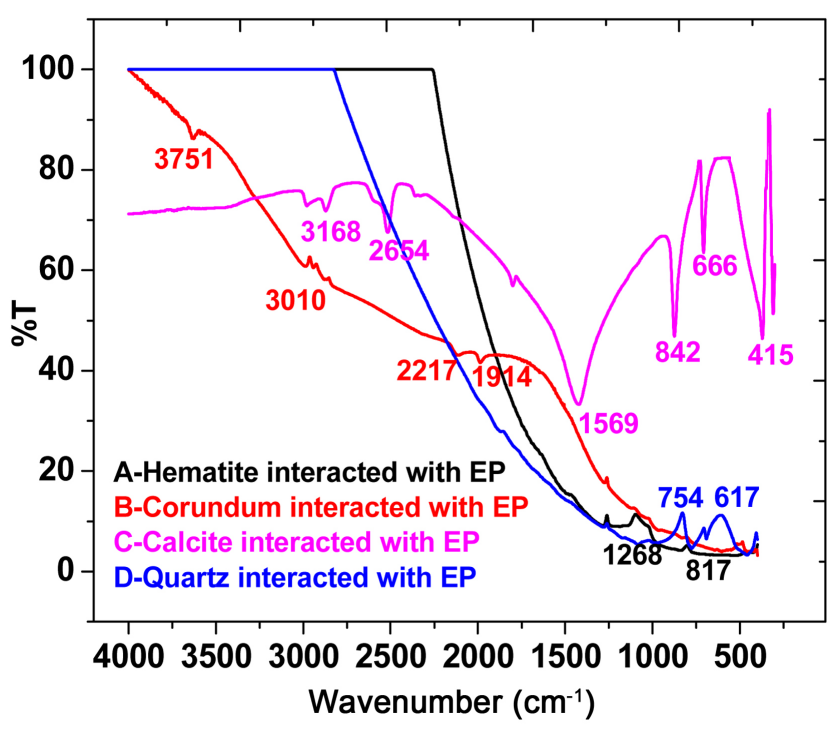

(b)

Figure 5. FTIR spectra of (a) Extracellular proteins (EP) (b) Interacted hematite, corundum, calcite and quartz.

sharp peaks were not observed in case of hematite, corundum and quartz but calcite showed the presence of sharp and specific peaks. Hydroxyl groups, Carboxylic acids and $1^{\circ}$ amines groups are not present in quartz and shows the difference between calcite and quartz after interaction. In case of hematite, 1268 $\mathrm{cm}^{-1}(\mathrm{~m})$ with C-H Wag $\left(-\mathrm{CH}_{2} \mathrm{X}\right)$ shows the presence of alkyl halides, $815 \mathrm{~cm}^{-1}$ (m) with $\mathrm{C}-\mathrm{Cl}$ stretch shows alkyl halide groups were observed, for corundum $3010 \mathrm{~cm}^{-1}(\mathrm{~m})$ with $=\mathrm{C}-\mathrm{H}$ stretch shows alkenes, $2217 \mathrm{~cm}^{-1}(\mathrm{w})$ with $\mathrm{C}=\mathrm{N}$ stretch shows alkyne groups and $1914 \mathrm{~cm}^{-1}(\mathrm{~m})$ with $-\mathrm{C}=\mathrm{C}$ - stretch shows the presence of alkyne groups were seen, for calcite, $3168 \mathrm{~cm}^{-1}(\mathrm{~s}, \mathrm{~b})$ with $\mathrm{O}-\mathrm{H}$ stretching hydroxyl groups shows the presence of alcohols and phenols, $2654 \mathrm{~cm}^{-1}$ 
$(\mathrm{m}, \mathrm{b})$ with $\mathrm{O}-\mathrm{H}$ stretching shows carboxylic acids, $1569 \mathrm{~cm}^{-1}$ (m) with $\mathrm{N}-\mathrm{H}$ bend shows $1^{\circ}$ amines, $842 \mathrm{~cm}^{-1}(\mathrm{~m})$ with $\mathrm{C}-\mathrm{Cl}$ stretch shows alkyl halide groups and also presence of calcite peaks, $666 \mathrm{~cm}^{-1}(\mathrm{~m})$ with $\mathrm{C}-\mathrm{Br}$ stretch, shows alkyl halides groups were found and in case of quartz only $754 \mathrm{~cm}^{-1}$ (m) with C-Cl stretch shows alkyl halide groups and 617 with C-Br stretch shows alkyl halides group were found.

\section{Matrix Assisted Laser Desorption Ionization-Time of Flight (MALDI-TOF) Mass Spectrometry Studies}

MALDI-TOF studies were performed to check the molecular weights of extracellular proteins secreted by bacteria in presence of minerals. The molecular weight of extracellular proteins of B. subtilis was in the range of $5000-10,000 \mathrm{Da}$ (Figure 6) and in presence of hematite (Figure 7) molecular weight was found more i.e. 4000 - 18,000 Da, in case of corundum (Figure 8) and calcite (Figure 9) interacted EP molecular weight was found to be 4000 - 15,000 Da and quartz (Figure 10) interacted EP was found to be 4000 - 20,000 Da.

\section{Discussion}

Similar studies were carried by using hematite, quartz, kaolinite and apatite from geological museum of China and their purities were found to be around 99\% [15]. The findings of FTIR spectra of corundum are in agreement with [16] and the results obtained by [15] for interaction of hematite before and after with $R$. erythropolis have shown that after interaction, new surface species were found and it also proved that adsorption occurs mainly chemical adsorption which makes hematite surface hydrophobic and enhance the floatability. Similar functional groups in quartz have been observed by [17] wherein they have shown

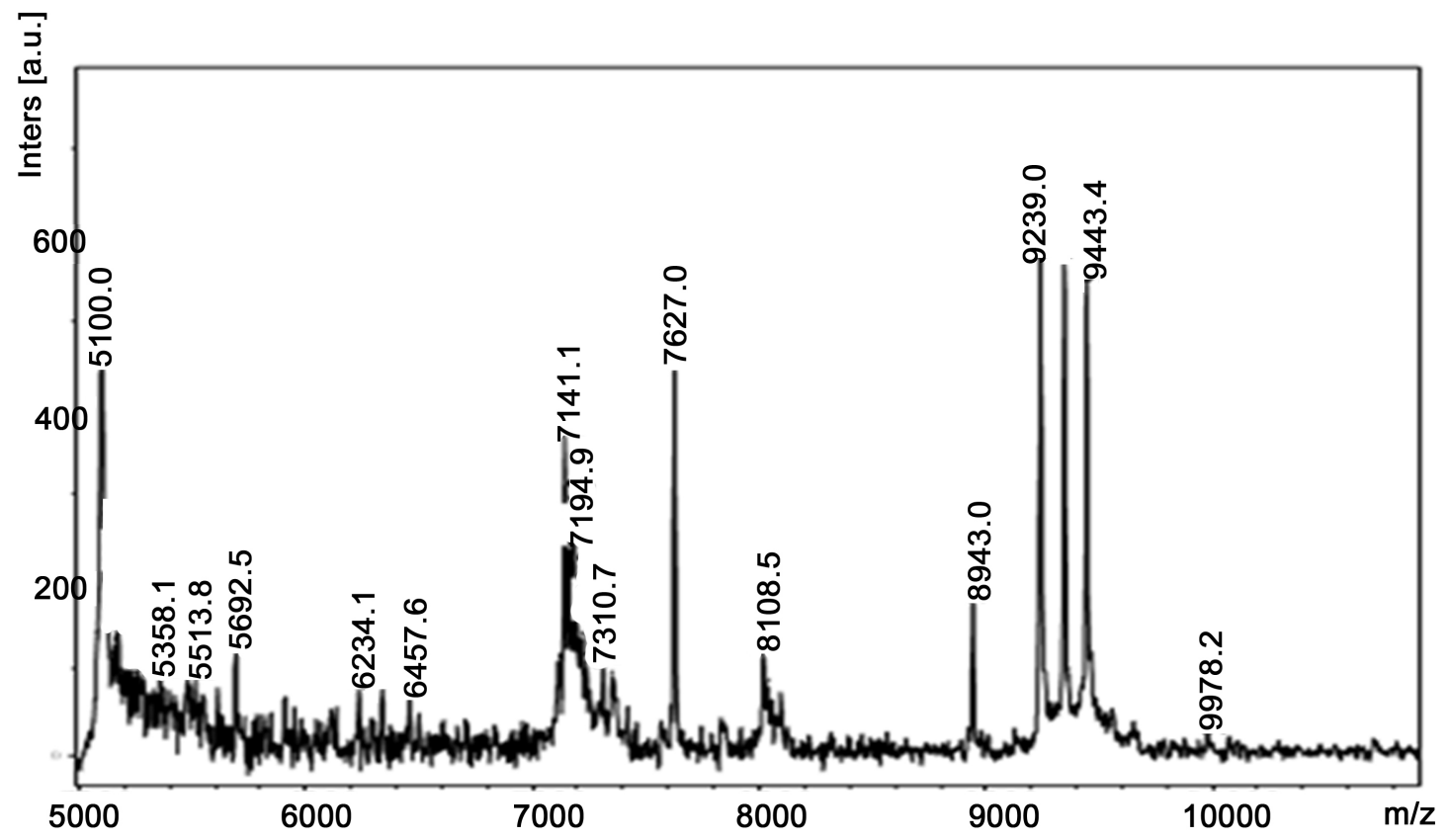

Figure 6. MALDI-TOF mass spectrum of control. 


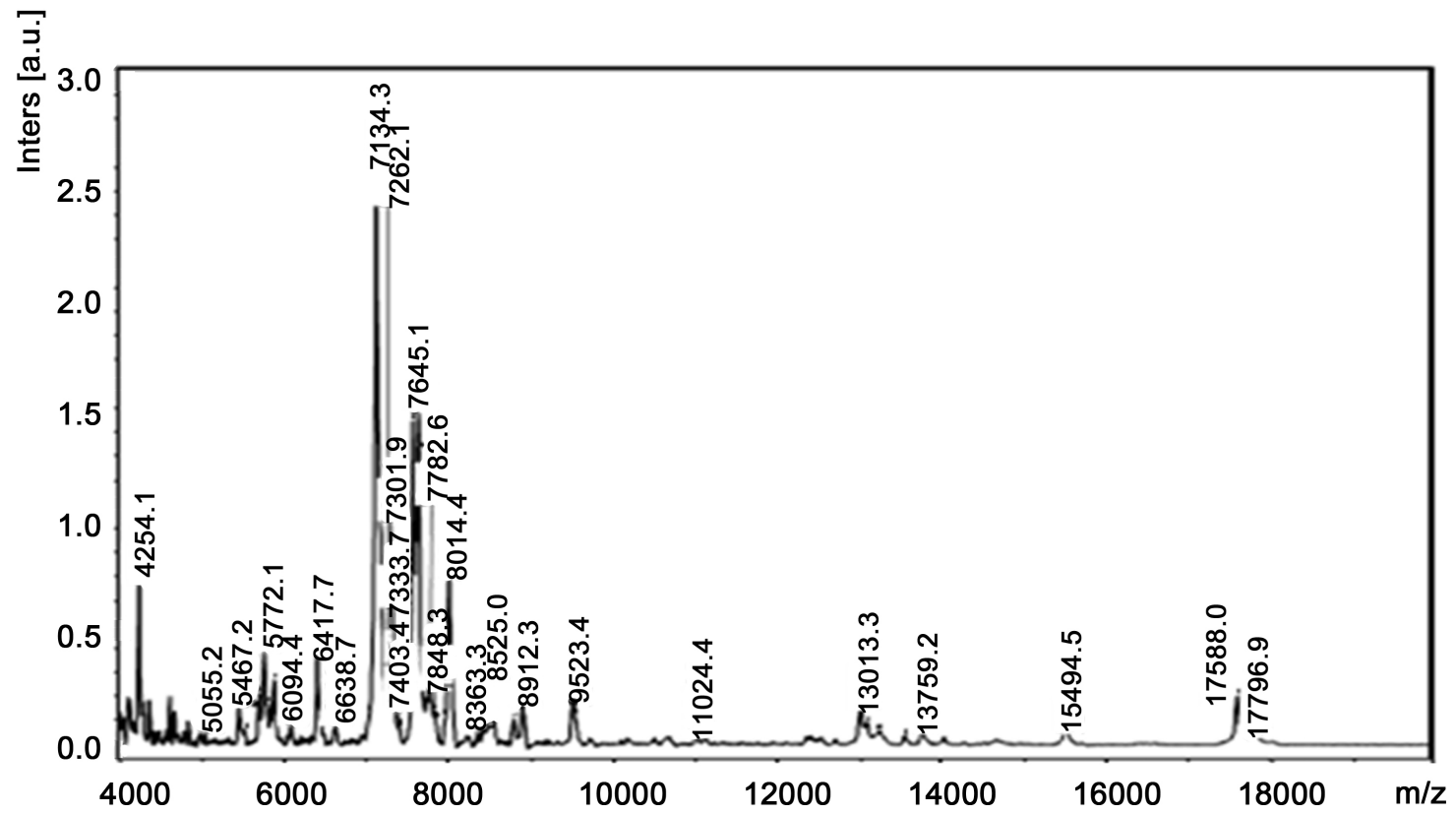

Figure 7. MALDI-TOF mass spectrum EP in presence of hematite.

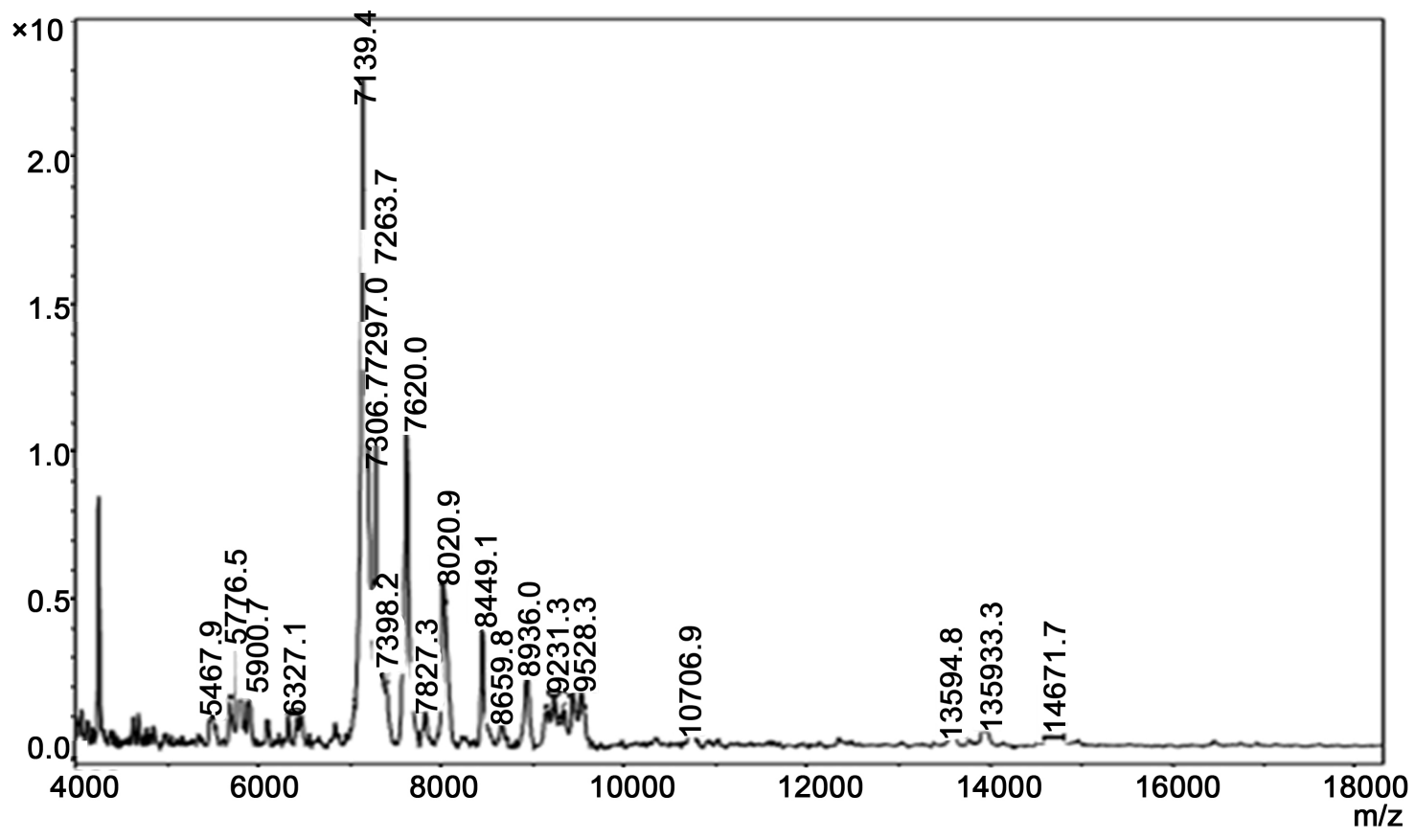

Figure 8. MALDI-TOF mass spectrum EP in presence of corundum.

that in presence of $R$. opacus calcite showed the characteristic bands of carbonates. The FTIR spectra of cell free extract interacted with minerals were observed by [16] and the shift in peaks was observed due to the presence of polysaccharides on hematite and corundum. Similar results in case of quartz which shows the presence of proteinaceous groups also observed by [18]. Similar studies of interaction with extracellular proteins were carried out for sphalerite and galena. MALDI-TOF studies were performed to check the molecular weights of extracellular proteins secreted by bacteria in presence of minerals and 


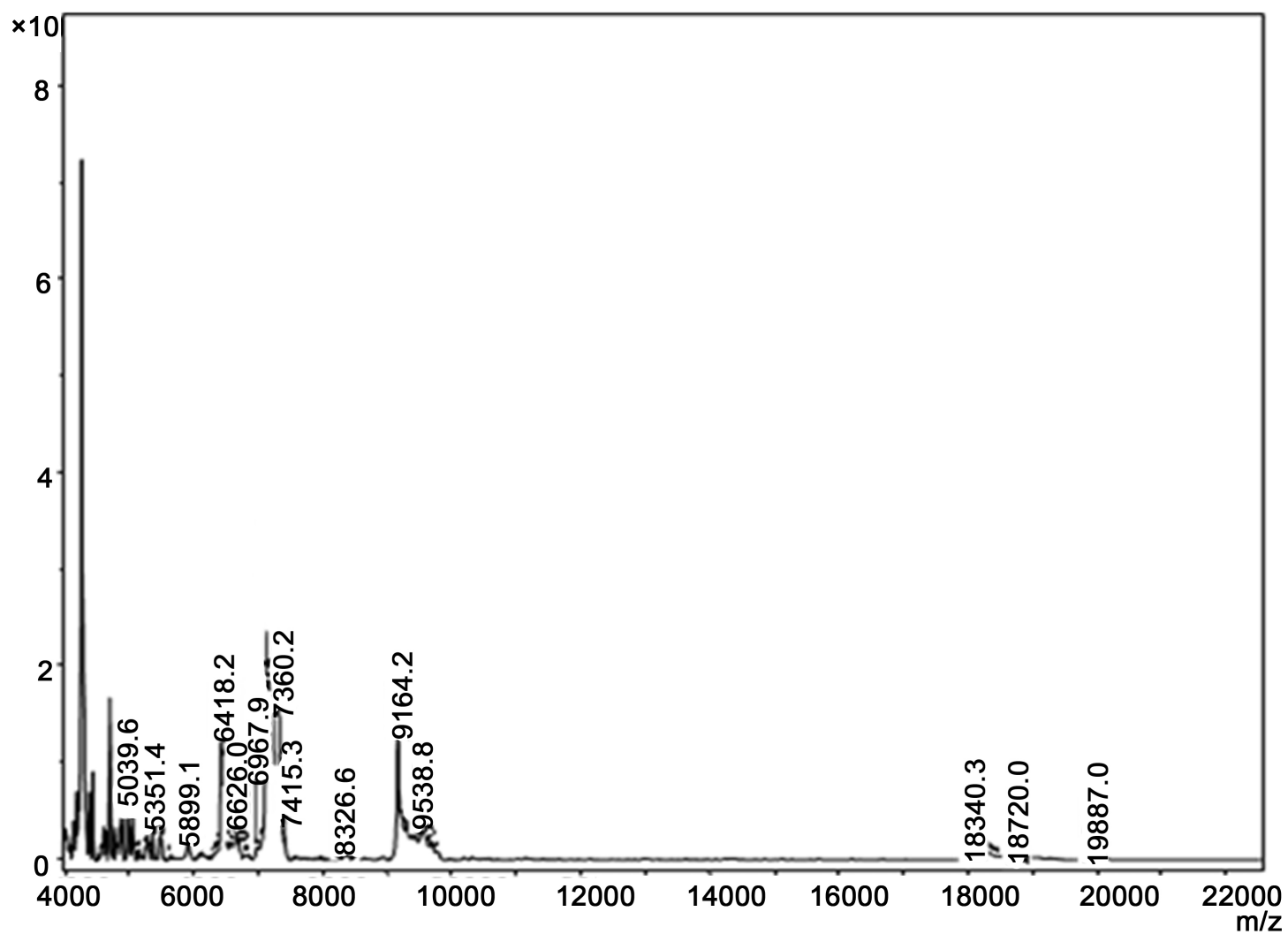

Figure 9. MALDI-TOF mass spectrum EP in presence of calcite.

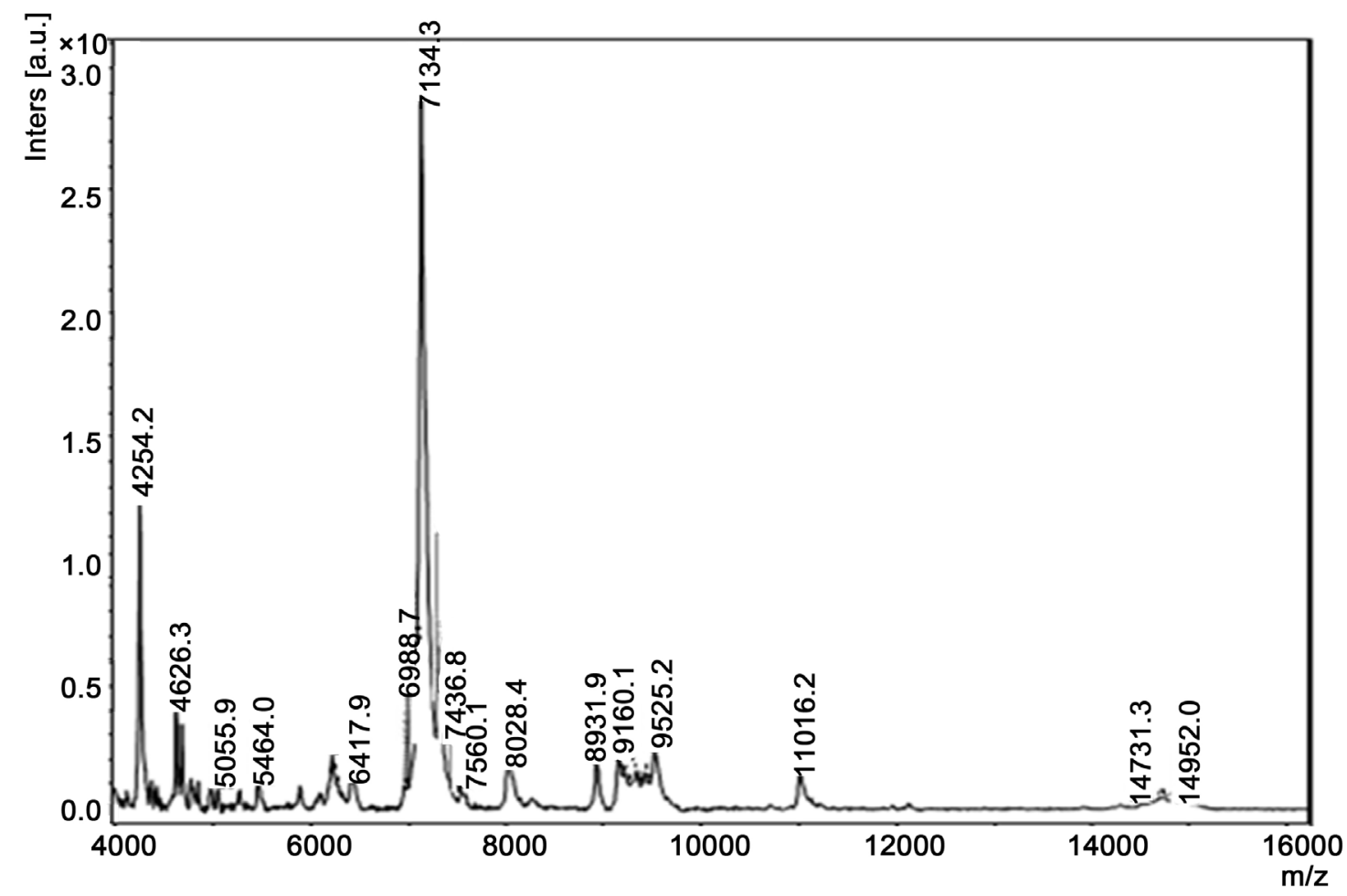

Figure 10. MALDI-TOF mass spectrum EP in presence of quartz.

are in agreement with the results obtained through SDS-PAGE. Similar findings 
have been reported by [6] in case of cytosolic proteins of At. ferrooxidans. FTIR and MALDI-TOF studies give us substantial understanding about the functional groups which will help us to prepare right floatation and flocculating agents to make the technology more efficient.

\section{Conclusions}

The characterization of minerals and growth kinetics of Bacillus subtilis was established. With relevance to iron ore beneficiation, growth kinetics of B. subtilis cells exhibited highest affinity towards hematite when compared to corundum, calcite and quartz. Bacterial adhesion was observed to be significantly higher on hematite and hematite could be effectively separated from corundum, calcite and quartz through microbially induced selective flocculation and flotation.

Extracellular protein exhibited higher affinity towards quartz compared to calcite and corundum and extracellular protein exhibited lower affinity towards hematite. Mineral induced proteins were expressed when bacterial cells were adapted to quartz, corundum, calcite and hematite. Mineral specific intracellular proteins were expressed when bacterial cells were grown in presence of hematite, corundum, calcite and quartz.

The FTIR studies showed significant appearance of new functional groups on interaction of minerals and the MALDI-TOF results showed the secretion of higher molecular weight of proteins and these results are in accord with those obtained by SDS-PAGE analyses.

\section{Acknowledgements}

The authors are thankful to Council of Scientific \& Industrial Research (CSIR), Government of India, New Delhi for financial support, Indian Institute of Science and Bangalore University for the infrastructure.

\section{References}

[1] Natarajan, K.A. (1998) Microbes Minerals and Environment. Geological Survey of India. Allied Publishers, Bangalore.

[2] Natarajan, K.A. and UshaPadukone, S. (2012) Microbial Induced Separation of Quartz from Hematite Using Yeast Cells and Metabolites. Minerals and Metallurgical Processing Journal, 29, 81-87.

[3] Madigan, M.J. and MartinkoBrock, J. (2005) Biology of Microorganisms. 11th Edition, Prentice Hall, Upper Saddle River.

[4] Jha, S.S., Joshi, S.J. and Geetha, S.J. (2016) Lipopeptide Production by Bacillus subtilis R1 and Its Possible Applications. Brazilian Journal of Microbiology, 47, 955-964. https://doi.org/10.1016/j.bjm.2016.07.006

[5] VanderWal, A., Minor, M., Norde, W., Zehnder, A.J.B. and Lyklema, J. (1997) Electrokinetic Potential of Bacterial Cells. Langmuir, 131, 265-271.

[6] Chandraprabha, M.N. (2007) Surface Studies on Sulphide Minerals and Aciditho bacillus Bacteria with Respect to Beneficiation and Bioremediation. Doctoral Thesis, Indian Institute of Science, Bangalore.

[7] Charun, Y. and John Farmer, G.A. (2006) Comparative Study of Acid-Extractable 
and Total Digestion Methods for the Determination of Inorganic Elements in Peat Material by Inductively Coupled Plasma-Optical Emission Spectrometry. Analytica Chemica Acta, 557, 296-303. https://doi.org/10.1016/j.aca.2005.10.043

[8] Clegg, W. (1998) Crystal Structure Determination. Oxford Chemistry Primer, Oxford University Press, Oxford.

[9] Goldstein, J. (2003) Scanning Electron Microscopy and X-Ray Microanalysis. 3rd Edition, Springer, Berlin. https://doi.org/10.1007/978-1-4615-0215-9

[10] Sambrook, J., Fritsch, E.F. and Maniatis, T. (1989) Molecular Cloning: A Laboratory Manual. Cold Spring Harbor Laboratory, New York.

[11] Abdel-Aziz, S.M., Hamed, H.A., Mouafi, F.E. and Abdelwahed, N.A.M. (2011) Extracellular Metabolites Produced by a Novel Strain, Bacillus alvei NRC-14: 3. Synthesis of a Bioflocculant That Has Chitosan-Like Structure. Life Science Journal, $16,883-890$.

[12] Ugbenyen, A.M. and Okoh, A.I. (2013) Flocculating Properties of a Bioflocculant Produced by Bacillus sp. Isolated from Marine Environment in South Africa. Chemical and Biochemical Engineering Quarterly, 27, 511-518.

[13] Sauro, B., Alexia, N., Gloess, I., Ingo, M. and Frederic, P. (2014) Analysis of the Structure of Condensed Tannins in Water Extracts from Bark Tissues of Norway Spruce (Piceaabies [Karst.]) and Silver fir (Abiesalba [Mill.]) Using MALDI-TOF Mass Spectrometry. Industrial Crops and Products, 61, 430-437. https://doi.org/10.1016/j.indcrop.2014.07.038

[14] Tatzber, M., Mutsch, F., Mentler, A., Leitgeb, E., Englisch, M. and Gerzabek, M.H. (2010) Determination of Organic and Inorganic Carbon in Forest Soil Samples by Mid-Infrared Spectroscopy and Partial Least Squares Regression. Applied Spectroscopy, 64, 1167-1175. https://doi.org/10.1366/000370210792973460

[15] Huifen, Y., Qiongyao, T., Chuanlong, W. and Jinlong, Z. (2013) Flocculation and Flotation Response of Rhodococcus erythropolis to Pure Minerals in Hematite Ores. Minerals Engineering, 45, 67-72. https://doi.org/10.1016/j.mineng.2013.01.005

[16] Namita, D. (1998) Studies on Biobeneficiation and Bioremediation Using Bacillus polymyxa with Reference to Iron Ore and Bauxite Processing. Doctoral Thesis, Indian Institute of Science, Bangalore.

[17] Botero, A.E.C., Torem, M.L. and Mesquita, L.M.S. (2007) Fundamental Studies of Rhodococcus opacus as a Biocollector of Calcite and Magnesite. Minerals Engineering, 20, 1026-1032. https://doi.org/10.1016/j.mineng.2007.03.017

[18] Santhiya, H. (2001) Investigations into the Surface Chemistry of Galena, Sphalerite and Sulphur Minerals Using Thiobacillus thiooxidans and Bacillus polymyxa. Doctoral Thesis, Indian Institute of Science, Bangalore. 
Submit or recommend next manuscript to SCIRP and we will provide best service for you:

Accepting pre-submission inquiries through Email, Facebook, LinkedIn, Twitter, etc. A wide selection of journals (inclusive of 9 subjects, more than 200 journals)

Providing 24-hour high-quality service

User-friendly online submission system

Fair and swift peer-review system

Efficient typesetting and proofreading procedure

Display of the result of downloads and visits, as well as the number of cited articles Maximum dissemination of your research work

Submit your manuscript at: http://papersubmission.scirp.org/

Or contact jep@scirp.org 